\title{
Quantitative Assessment of Epiphytic and Benthic Meioinvertebrate Fauna in Various Types of Standing Water
}

\author{
Teresa Nesteruk \\ Faculty of Natural Science, Department of Zoology, Siedlce University of Natural Sciences and Humanities,
} B. Prusa 12, 08-110 Siedlce, Poland

Received: 9 September 2015

Accepted: 2 April 2016

\begin{abstract}
The density and dominance of benthic and epiphytic fauna of selected meioinvertebrate groups were studied in various types of standing water in eastern Poland: two lakes (mesotrophic and polytrophic) and two small water bodies (an oligotrophic pond and a peat-hag). The plants from which the fauna were collected included: Ceratophyllum demersum L., Elodea canadensis Michx., Hydrocharis morsus-ranae L., Myriophyllum spicatum L., Nuphar lutea (L.) Sibth. (i) Sm., Potamogeton natans L., and Stratiotes aloides L. In the taken material, the density and dominance structure of benthic and epiphytic fauna of the taxa Turbellaria, Gastrotricha, Rotifera, and Nematoda were estimated. Total density of the studied phyla in bottom sediments and on elodeids fluctuated from 1315.0 to $3156.010^{3}$ indiv. $\mathrm{m}^{-2}$, and from 2078.0 to $3954.010^{3}$ indiv. $\mathrm{m}^{-2}$, respectively. Mean density of meioinvertebrates per $100 \mathrm{~g}$ dry weight of plants in the studied waterbodies amounted to from 125.8 to $289.010^{3}$ indiv. $100 \mathrm{~g}^{-1}$ d.w.

The density of meioinvertebrate fauna of elodeids was higher than in bottom sediments in all studied reservoirs and the differences were statistically significant.

Epiphytic meioinvertebrate fauna in Lake Bikcze of high trophic level shows low similarity to the mesotrophic one, and to the oligotrophic pond, but shows high similarity to the peat-hag. The development of the meioinvertebrate community on elodeids is mainly affected by the trophic status of the reservoir and not by the character of vegetation.
\end{abstract}

Keywords: meioinvertebrates, standing water, density, bottom sediments, elodeids

\section{Introduction}

Meioinvertebrates are a regular part of inland water ecosystems. They are present in fertile bottom sediments and aquatic vegetation. Lakes and small water bodies

*e-mail: teresa.nesteruk@uph.edu.pl (ponds, clay pits, peat-hags) are thus optimal habitats for many invertebrate taxa. Habitat diversity ensures species diversity in communities. Consequently, the diversity of species in the environment affects the performance of biocenoses and cycles of matter in a landscape [1].

Meioinvertebrate fauna feeds on algae and bacteria that are taken together with the remains of organic matter. Epiphytic algae are an important component of aquatic 
biocenosis. The biomass of epiphytic algae occurring on submerged macrophytes is much higher in spring and autumn than in summer [2].

Epiphytic meioinvertebrate fauna consists of the same taxonomic groups as bottom sediment fauna, although it plays a different role in the functioning of aquatic ecosystems. It cannot therefore be considered in the environment as a single group [3-6]. The majority of the taxa is associated with a specific substrate: mud, sand, or stone habitats. Some species of epiphytic invertebrate fauna are present in bottom sediments. Seasonal migration from plant surfaces to bottom sediments has been observed, and it usually occurs in autumn when the vegetation declines [7]. Migration can affect the density of invertebrate fauna in both habitats. The biological and physico-chemical structure of near-bottom habitats located under densely growing submerged vegetation, and their significance in the functioning of whole aquatic ecosystems, are very little known due to difficulties in sampling [8].

In the present study, the density of epiphytic and bottom sediment faunae is assessed as the number of individuals per unit of bottom area for selected meioinvertebrate groups in various types of standing water. The main goal of this study is to compare selected meionvertebrate groups living in bottom sediments and on elodeids. Moreover, the presented work is an attempt to answer the question of whether the character of plants influences the abundance of selected meionvertebrate groups.

\section{Area of Study}

The studies were carried out in two lakes of different trophic status: Piaseczno (mesotrophic) and Bikcze (strongly eutrophic), situated about $170 \mathrm{~km}$ south-east of Warsaw, Poland in the region of Polesie Lubelskie, and from two small reservoirs (denoted A and B) located about $100 \mathrm{~km}$ east of Warsaw, Poland.

Lake Piaseczno covers 83.8 ha and its maximum depth is $38.8 \mathrm{~m}$. The northern part of the lake is narrow and deep, the southern part is wide and shallow. The lake is surrounded by a sandy beach $20-30 \mathrm{~m}$ wide, and only its southern shallow part borders the transitional moor. The bottom of the lake, especially in the northern and northwestern parts, is densely overgrown by Charales, while Elodea canadensis Michx., Ceratophyllum demersum L., and Myriophyllum spicatum L. occur in the water column. Water $\mathrm{pH}$ was 7.10 , and $8.30 \mathrm{mg} \mathrm{cm}^{-3}$ of dissolved oxygen was found [9].

Lake Bikcze covers 85 ha and maximum depth is $3.3 \mathrm{~m}$. The bottom of the lake is silted in its southern part and sandy in the eastern part. The lake is surrounded by a dense growth of Scirpo-Phragmicetum Koch 1926. Scattered patches of Schoenoplectus lacustris (L.) Palla are to be found in the south, while several meters-wide belts of Stratiotes aloides L. connecting the littoral vegetation with the peaty eulittoral occur around the southern, northern, and western shores. Nuphar lutea (L.) Sibth (i) Sm. and Potamogeton natans L. are found in the southern and southeastern parts of the lake, while in the littoral there is a dense belt of Elodea canadensis Michx. Water $\mathrm{pH}$ ranged from 8.01 to 9.14 , and $11.94 \mathrm{mg} \mathrm{cm}^{-3}$ of dissolved oxygen was found [10].

Reservoir (A) is a $30 \mathrm{~m}^{2}$ (10 m long, $3 \mathrm{~m}$ wide) meadow peat-hag of $60 \mathrm{~cm}$ average depth. Water $\mathrm{pH}$ ranged from 5.20 to 6.20 . The dissolved oxygen content in the near-bottom water layer was from 2.80 to $3.60 \mathrm{mg} \mathrm{cm}{ }^{-3}$. The shore of the reservoir is covered with birch (Betula pubescens Ehrh., B. pendula Roth) and alder (Alnus glutinosa (L.) Gaertn). The water vegetation includes: Lemna sp., Hydrocharis morsus-ranae L., Potamogeton natans L., Caltha palustris L., Comarum palustre L., and Typha latifolia L.

Reservoir (B), with a surface of $60 \mathrm{~m}^{2}$ (10 m long, $6 \mathrm{~m}$ wide), is a young oligotrophic pond of 50 to $150 \mathrm{~cm}$ depth. Water $\mathrm{pH}$ ranged from 6.40 to 8.40 , and 6.30 to $8.10 \mathrm{mg} \mathrm{cm}^{-3}$ of dissolved oxygen was found. It has a high shore; its bottom is sandy with a clay bedding, and contains a thin layer of the organic sediment. The eastern part of the reservoir hosts Typha angustifolia L., Carex sp. and Sparganium erectum L. Emend. Rchb. s. str. Submerged plants consist of Elodea canadensis Michx.

\section{Methods}

Samples from three sites at a depth of about 0.5 to $1.5 \mathrm{~m}$ in both lakes, and reservoirs $\mathrm{A}$ and $\mathrm{B}$, were collected four times for two consecutive vegetative seasons (April, June, August, and October) in 2010 and 2011. During the whole study period, 24 samples from plants and 24 samples in bottom sediments were collected from each reservoir.

In the taken material, the density and dominance structure of benthic and epiphytic fauna of the taxa Turbellaria, Gastrotricha, Rotifera, and Nematoda were estimated.

Aquatic plants from which the fauna was collected include: Ceratophyllum demersum L., Elodea canadensis Michx., and Myriophyllum spicatum L. in Lake Piaseczno; E. canadensis Michx., Nuphar lutea (L.) Sibth. (i) Sm., Stratiotes aloides L., and Potamogeton natans L. in Lake Bikcze; E. canadensis Michx., Hydrocharis morsus-ranae L., and P. natans L. in reservoir A; and E. canadensis Michx. in reservoir B.

A square metal frame with half meter-long sides was placed at the bottom of the reservoir. All the plants were thus collected from an area restricted to $0.25 \mathrm{~m}^{2}$ and put with water into a 101 container. The water was then squeezed out from the plants. The surfaces of Hydrocharis morsus-ranae L., Nupha lutea (L.) Sibth. (i) Sm., Potamogeton. natans L., and Stratiotes aloides L. collected from the water surface above the frame, were scraped with a scalpel and rinsed with distilled water. The whole material collected in that way was mixed with the water squeezed from the plants. Five containers were then taken from that (each of $200 \mathrm{~cm}^{3}$ volume) and used to determine invertebrate density and percentage share 
of particular taxa in the total fauna of invertebrates. In order to compare density of epiphytic fauna with that of bottom sediments, the latter should be related not only to the unit of weight, but also to the area of the bottom overgrown by elodeids.

The density was investigated in each container. A mixed portion of $2 \mathrm{~cm}^{3}$ was taken from each container. The number of specimens in $2 \mathrm{~cm}^{3}$ was calculated in the whole volume $\left(200 \mathrm{~cm}^{3}\right)$ of each of the five containers, and then in the whole volume of the collected sample. With the known surface area of a square metal frame $\left(0.25 \mathrm{~m}^{2}\right)$ and the number of individuals in the whole volume of the collected sample, the number of individuals per $\mathrm{m}^{2}$ of bottom area could be calculated. The plants, which the fauna was selected from, were weighed, dried, and then weighed again in the laboratory. Then the density of fauna living on elodeids per $100 \mathrm{~g}$ dry weight of plants was calculated.

Samples from bottom sediments were taken with the use of a tubular bottom corer with a cross-section surface area of $10.4 \mathrm{~cm}^{2}$. The upper $10 \mathrm{~cm}$ sediment layer was examined. The density of each phyla were calculated per $\mathrm{m}^{2}$ of bottom surface. The whole methodology presented in this paper has been previously applied to similar studies concerning farm ponds [5].

The percentage contribution of invertebrate groups in the studied reservoirs was determined from the formula $\mathrm{D}=100 \mathrm{n} / \mathrm{N}$, where $\mathrm{n}$ is the number of individuals of a given taxa and $\mathrm{N}$ is the number of all individuals of the ascertained taxa.

The similarity of the fauna in the four reservoirs was assessed from the index of homogeneity [11]:

$$
H D=\sum_{i=1}^{s}\left(\sum_{j=1}^{k} \frac{D_{i j}}{k}\right) \frac{D_{\min _{i}}}{D_{\max _{i}}}
$$

... where $\mathrm{D}_{\mathrm{ij}}$ is the dominance index of the $i$ th individual of taxa at the $j$ th stand with a total of $s$ individuals of all taxa.

The material for characterization of physicochemical water parameters in reservoirs A and B was collected four times over the course of the study. $\mathrm{pH}$ and oxygen content were determined in these samples. The analysis of water parameters was performed using an oxygen meter

Table 1. Density and percentage contribution of particular taxa of meioinvertebrates in their total abundance in the studied reservoirs (mean values, $\mathrm{n}=24$ ).

\begin{tabular}{|c|c|c|c|c|c|c|c|c|c|c|}
\hline \multirow{2}{*}{ Reservoirs } & \multirow{2}{*}{ Taxa } & \multicolumn{3}{|c|}{ Bottom sediments } & \multicolumn{6}{|c|}{ Aquatic plants } \\
\hline & & $\mathrm{A}$ & SD & $\mathrm{D}$ & A & SD & $\mathrm{D}$ & $\mathrm{E}$ & $\mathrm{SD}$ & $\mathrm{D}$ \\
\hline \multirow{4}{*}{$\begin{array}{c}\text { Lake } \\
\text { Piaseczno }\end{array}$} & Turbellaria & 85 & \pm 25 & 3.8 & 130 & \pm 45 & 4.5 & 5.7 & \pm 3 & 3.0 \\
\hline & Gastrotricha & 742 & \pm 210 & 33.1 & 980 & \pm 180 & 33.4 & 56.0 & \pm 27 & 29.6 \\
\hline & Rotifera & 395 & \pm 100 & 17.6 & 420 & \pm 158 & 14.3 & 30.6 & \pm 12 & 16.1 \\
\hline & Nematoda & 1020 & \pm 270 & 45.5 & 1402 & \pm 290 & 47.8 & 97.2 & \pm 31 & 51.3 \\
\hline Total & & 2242.0 & & 100.0 & 2932.0 & & 100.0 & 189.5 & & 100.0 \\
\hline \multirow{4}{*}{$\begin{array}{c}\text { Lake } \\
\text { Bikcze }\end{array}$} & Turbellaria & 34 & \pm 18 & 1.3 & 48 & \pm 11 & 1.5 & 3.7 & \pm 2 & 1.6 \\
\hline & Gastrotricha & 1255 & \pm 290 & 46.4 & 1460 & \pm 305 & 46.3 & 102.0 & \pm 40 & 45.4 \\
\hline & Rotifera & 1020 & \pm 225 & 37.7 & 966 & \pm 248 & 30.6 & 69.0 & \pm 28 & 30.7 \\
\hline & Nematoda & 395 & \pm 98 & 14.6 & 682 & \pm 157 & 21.6 & 50.2 & \pm 20 & 22.3 \\
\hline Total & & 2704.0 & & 100.0 & 3156.0 & & 100.0 & 224.9 & & 100.0 \\
\hline \multirow{4}{*}{$\begin{array}{c}\text { Reservoir } \\
\text { A }\end{array}$} & Turbellaria & 22 & \pm 8 & 0.7 & 34 & \pm 14 & 0.8 & 2.2 & \pm 2 & 0.8 \\
\hline & Gastrotricha & 1750 & \pm 350 & 55.4 & 1960 & \pm 295 & 49.6 & 140.4 & \pm 45 & 50.1 \\
\hline & Rotifera & 1120 & \pm 205 & 35.5 & 1280 & \pm 200 & 32.4 & 85.0 & \pm 27 & 30.4 \\
\hline & Nematoda & 264 & \pm 80 & 8.4 & 680 & \pm 170 & 17.2 & 52.4 & \pm 18 & 18.7 \\
\hline Total & & 3156.0 & & 100.0 & 3954.0 & & 100.0 & 280.0 & & 100.0 \\
\hline \multirow{4}{*}{$\begin{array}{c}\text { Reservoir } \\
\text { B }\end{array}$} & Turbellaria & 88 & \pm 25 & 6.7 & 120 & \pm 60 & 5.8 & 7.1 & \pm 4 & 5.6 \\
\hline & Gastrotricha & 483 & \pm 98 & 36.7 & 660 & \pm 220 & 31.8 & 31.9 & \pm 19 & 25.4 \\
\hline & Rotifera & 180 & \pm 35 & 13.7 & 318 & \pm 80 & 15.3 & 19.8 & \pm 8 & 15.7 \\
\hline & Nematoda & 564 & \pm 120 & 42.9 & 980 & \pm 190 & 47.1 & 67.0 & \pm 21 & 53.3 \\
\hline Total & & 1315.0 & & 100.0 & 2078.0 & & 100.0 & 125.8 & & 100.0 \\
\hline
\end{tabular}

The density is given in: A - thousand indiv. $\mathrm{m}^{-2}$ and $\mathrm{E}$ - thousand indiv. $100 \mathrm{~g}^{-1}$ d.w. of plants;

$\mathrm{D}$ - percentage contribution (\%); SD - standard deviation. 
Table 2. Comparison between density of bottom sediments fauna and epiphytic fauna in the studied reservoirs. $\mathrm{N}$ - number of samples, $\mathrm{Z}$ - value of test function and $p$ - probability of the Mann-Whitney U-test are given.

\begin{tabular}{|c|c|c|c|}
\hline Reservoir & N & Z & $p$ \\
\hline Piaseczno Lake & 24 & -5.93 & $<0.001$ \\
\hline Bikcze Lake & 24 & -2.84 & 0.005 \\
\hline Reservoir A & 24 & -4.09 & $<0.001$ \\
\hline Reservoir B & 24 & -5.75 & $<0.001$ \\
\hline
\end{tabular}

(Oxi 340i WTW GmbH \& Co.KG) and a digital pHmeter (CP-215 Elmetron).

Prior to statistical analysis, the distributions of variables were checked using the Shapiro-Wilk test. Since the distributions were not normal, nonparametric tests were used.

The Mann-Whitney test was used to compare density of fauna in bottom sediments and on elodeids in a particular reservoir, and the G-test was used to compare the dominance structure of meioinvertebrate fauna between bottom sediments and elodeids. The KruskalWallis test was employed for comparison of density of fauna between the studied reservoirs. The post-hoc Dunn's test was applied to check between which reservoirs the difference in density of fauna was statistically significant. In all the tests, the results were considered statistically significant if $p<0.05$. Analyses were performed by means of the program Statistica v. 12.0.

\section{Results}

Total density of the studied phyla in bottom sediments ranged from 1,315.0 (Reservoir B) to 3,156.0 $10^{3}$ indiv. $\mathrm{m}^{-2}$ (Reservoir A), and on elodeids from 2,078.0 (Reservoir B) to $3,954.010^{3}$ indiv. $\mathrm{m}^{-2}$ in Reservoir A. The density of meioinvertebrate fauna of elodeids was higher than in bottom sediments in all studied reservoirs (Table 1) and the differences were statistically significant (Table 2).

Comparison of all reservoirs in respect to density of meioinvertebrate organisms showed differences

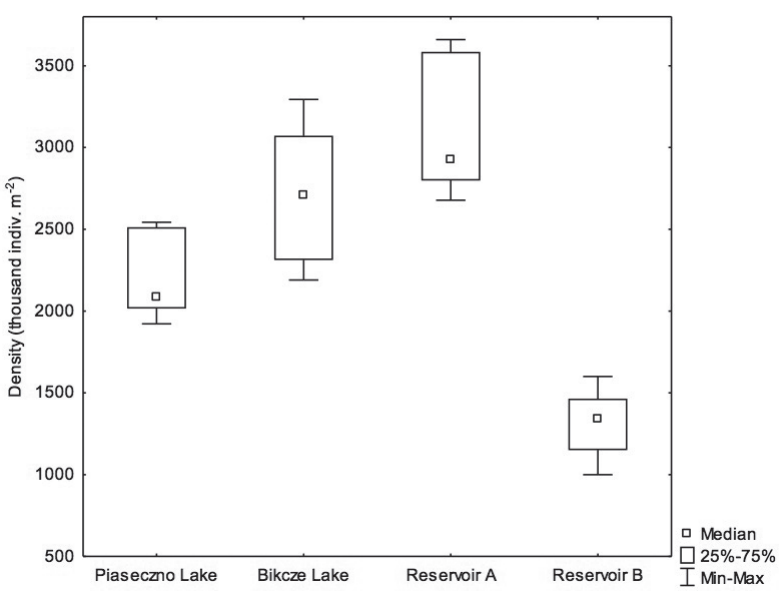

Fig 1. The density of invertebrate fauna of bottom sediments in the studied reservoirs (for each reservoir $\mathrm{N}=24$ ).

both in the bottom sediments (Kruskal-Wallis test $\mathrm{H}_{3.96}=73.78 ; p<0.001$ ) and on elodeids (Kruskal-Wallis test $\left.\mathrm{H}_{3.96}=74.48 ; p<0.001\right)$. Densities of bottom sediments of Piaseczno Lake and Bikcze Lake were similar as were Bikcze Lake and Reservoir A (Table 3, Fig. 1). In the case of epiphytic fauna there were no differences only between Piaseczno Lake and Bikcze Lake (Table 3, Fig. 2).

Mean density of meioinvertebrates per $100 \mathrm{~g}$ dry weight of plants in studied reservoirs amounted to $280.010^{3}$ indiv. $100 \mathrm{~g}^{-1}$ d.w. in reservoir A (peat-hag) more than two times higher than in reservoir B $\left(125.810^{3}\right.$ indiv. $100 \mathrm{~g}^{-1}$ d.w.).

In Lake Bikcze and reservoir A (peat-hag) the most numerous were Gastrotricha and Rotifera. The percentage contribution of Gastrotricha to the whole studied fauna in Lake Bikcze and Reservoir A was from 46.4 to $55.4 \%$ and 46.3 to $49.6 \%$ in bottom sediments and on plants, respectively. Among the studied taxa the least numerous was Turbellaria. Its percentage share in the whole studied benthic and epiphytic fauna in all the reservoirs was from 0.7 to $6.7 \%$ (Table 1). The dominance structures of benthic and epiphytic meioinvertebrate faunae were similar in a particular reservoir (G-test, in all cases $p>0.05)$.

Table 3. Differences in density of bottom sediments fauna and epiphytic fauna between particular reservoirs. $\mathrm{Z}$ - value of test function and $p$ - probability of the Dunn post-hoc test are given.

\begin{tabular}{|c|c|c|c|c|}
\hline \multirow{2}{*}{ Reservoirs } & \multicolumn{2}{|c|}{ Bottom sediments } & \multicolumn{2}{c|}{ Epiphytic fauna } \\
\cline { 2 - 5 } & Z & $p$ & Z & 0.547 \\
\hline Piaseczno Lake and Bikcze Lake & 2.46 & 0.083 & 1.69 & $<0.001$ \\
\hline Piaseczno Lake and Reservoir A & 4.50 & $<0.001$ & 4.58 & $<0.001$ \\
\hline Piaseczno Lake and Reservoir B & 3.65 & 0.002 & 3.85 & 0.023 \\
\hline Bikcze Lake and Reservoir A & 2.04 & 0.247 & 2.89 & $<0.001$ \\
\hline Bikcze Lake and Reservoir B & 6.11 & $<0.001$ & 5.54 & $<0.001$ \\
\hline Reservoir A and Reservoir B & 8.15 & $<0.001$ & 8.44 & $<$ \\
\hline
\end{tabular}




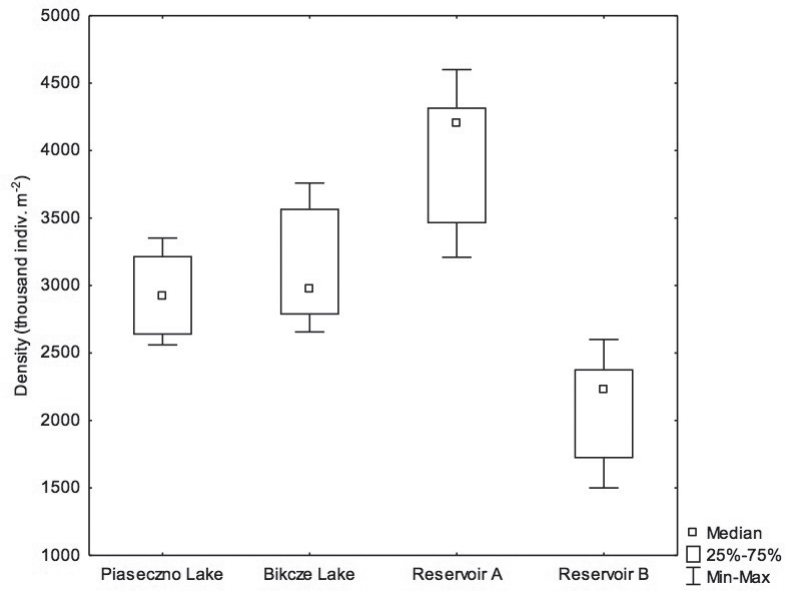

Fig. 2. The density of invertebrate fauna of elodeids in the studied reservoirs (for each reservoir $\mathrm{N}=24$ ).

The similarity of fauna of the bottom sediments in eutrophic Lake Bikcze and peat-hag (reservoir A), assessed on the basis of the homogeneity index, was high and amounted to $83.0 \%$, and of epiphytic fauna amounted to $90.0 \%$ (Table 4 ). Both reservoirs were characterized by a similar trophy and a similar structure of sediments. Similarity of the studied fauna of the bottom sediments in oligotrophic pond (B) to Lake Bikcze and Reservoir A was distinctly lower and amounted to 53.0 and $45.0 \%$, respectively. The similarity of epiphytic fauna in oligotrophic pond (B) to peat-hag (A) and Lake Bikcze ranged from 49.0 to $55.0 \%$.

The similarity between bottom sediment fauna and epiphytic fauna in each of the studied reservoirs, calculated according to the homogeneity index, was very high and ranged from $81 \%$ in reservoir A to $93 \%$ in Lake Piaseczno (Fig. 3).

\section{Discussion}

The obtained results show that organic bottom sediments are settled by numerous meioinvertebrate fauna. In Lake Bikcze and Reservoir A (peat-hag) the fauna density was higher than in the oligotrophic pond (Reservoir B). The similarity between the former two is also expressed by a similar structure of sediments. In both reservoirs, during the whole study period the most

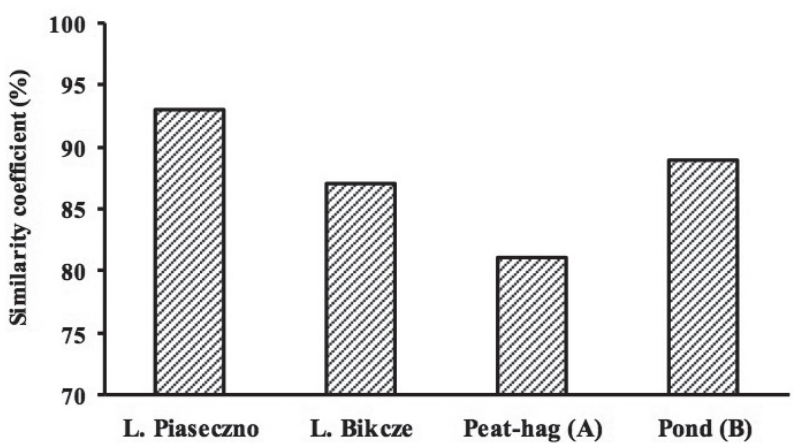

Fig. 3. Similarity between bottom sediment fauna and epiphytic fauna in each of the studied reservoirs calculated according to the homogeneity index (\%).

numerous were gastrotrichs and rotifers. For gastrotrichs, fertile sediments are the most fundamental habitat. In the organic bottom sediment they even reach the number of $2.6 \mathrm{mln}$ individuals $\mathrm{m}^{-2}$. Gastrotrichs reach such high numbers due to their low sensitivity to oxygen deficiency. In the organic bottom slime, they are abundant up to $17 \mathrm{~cm}$ in depth, so it can be thought that the conditions existing so deep in the slime are almost anoxic [12]. Moreover, gastrotrichs tolerate waters with a wide $\mathrm{pH}$ spectrum. They are abundant in waters from slightly acidic up to alkaline with $\mathrm{pH}=10.0$ [4]. High gastrotrich density in the studied Lake Bikcze and peat-hag (Reservoir A), higher than the rest of the phyla, shows that they constitute an essential element of water biocenosis. Moreover, shorter succession of generations of Gastrotricha than in other meioinvertebrate groups makes for greater annual output in comparison with other animal groups with longer life cycles. In both reservoirs (Lake Bikcze and peat-hag) rotifers were as numerous as gastrotrichs. Rotifers represent one of the basic groups of freshwater invertebrates. They occur in freshwater ecosystems, in almost all types of habitats. Rotifers are permanently present in small and large lakes of varying fertility, in ponds, and temporary puddles. They are important filter feeders of algae and bacteria [13].

Data related to the density of meiobenthos in fresh waters are scarce, so there is only a limited range of conclusions. A low density of Turbellaria was obtained from the studied reservoirs, in spite of the fact that turbellarians belong to typical representatives of freshwater fauna. Seasonal variation was observed

Table 4. Similarity of benthic and epiphytic fauna in the studied reservoirs calculated according to the homogeneity coefficient (\%).

\begin{tabular}{|c|c|c|c|}
\hline Reservoirs & $\begin{array}{c}\text { Eutrophic Lake } \\
(\text { Bikcze) }\end{array}$ & $\begin{array}{c}\text { Reservoir A } \\
\text { (peat-hag) }\end{array}$ & $\begin{array}{c}\text { Reservoir B } \\
\text { (oligotrophic pond) }\end{array}$ \\
\hline Mesotrophic Lake Piaseczno & $52.0^{\mathrm{b}} ; 56.0^{\mathrm{p}}$ & $45.0^{\mathrm{b}} ; 50.0^{\mathrm{p}}$ & $88.0^{\mathrm{b}} ; 95.0^{\mathrm{p}}$ \\
\hline Eutrophic Lake Bikcze & & $83.0^{\mathrm{b}} ; 90.0^{\mathrm{p}}$ & $53.0^{\mathrm{b}} ; 55.0^{\mathrm{p}}$ \\
\hline Reservoir A ( peat-hag) & & & $45.0^{\mathrm{b}} ; 49.0^{\mathrm{p}}$ \\
\hline
\end{tabular}

$\mathrm{b}$ - similarity of benthic fauna; $\mathrm{p}$ - similarity of epiphytic fauna 
in the species composition of turbellarians in the annual cycle, but no significant differences were found in the mean species richness [14].

In mesotrophic Lake Piaseczno and oligotrophic Reservoir B with the highest water oxygenation, the dominant group of bottom sediments and of elodeids was Nematoda. Free-living nematodes are a major component of freshwater meiofaunal communities, where they often attain very high densities ( $>1$ million individuals per $\mathrm{m}^{-2}$ ) [15]. Nematodes are a major food source for benthic and pelagic invertebrates. In inland waters they have a key position in the freshwater trophic chain $[16,17]$.

Nematodes prefer less fertile sediments and are dominant in habitats characterized by high oxygenation. The results of research conducted in the bottom sediments of the littoral in eight lakes of varying fertility (southern Sweden) showed that lake trophy has a strong impact on species diversity of nematodes. The greatest number of species was found in mesotrophic and oligotrophic lakes, while the abundance and biomass remained at a similar level. Overall, the results suggest that the trophic state of the lake is an important factor shaping the structure of nematodes in the littoral lakes [18].

So far, little research carried out on bottom sediment and epiphytic fauna has shown that the species structure, density, and biomass of elodeid fauna were equal to or even higher than those of bottom sediment fauna.

Species structure, abundance, and distribution of epiphytic and benthic invertebrates associated with stands of M. spicatum L. were studied in a shallow eutrophic lake in Poleski National Park (in the Polesie Lubelskie region of Eastern Poland). Bottom invertebrates showed visibly lower abundances than epiphytic ones, which could be a consequence of oxygen conditions. In the studied lake, M. spicatum L. created dense homogenous beds. It might be expected that under dense cover of vegetation, very low concentrations of dissolved oxygen might create inhospitable conditions for benthic animals [19].

The studies were conducted in small mid-forest water bodies located in the region of Greater Poland (in westcentral Poland), and showed that in the reservoir zones dominated by elodeids, rotifers are of the highest diversity and abundance [20]. The preference of rotifer species to habitats densely overgrown by macrophytes is often observed in lakes [21].

Submerged macrophytes are an important component of the characterization of the ecological status of water reservoirs. The first sign of change in the structure of macrophytes is their occurrence range [22]. However, the abundance and richness of underwater plant communities decreased due to anthropogenic activities. These impacts have caused severe declines in the range and abundance of many freshwater species, so that they are now far more imperiled than their marine or terrestrial counterparts $[23$, 24].

A long-term loss of macrophyte species diversity has also occurred in many shallow lakes affected by eutrophication. Conservation of the diversity of aquatic plants will rely on their ability to adapt to new ecological conditions. It is important to understand the nature and importance of species diversity of macrophytes in the functioning of the ecosystem and to restore the diversity of macrophytes in shallow lakes [25, 26].

Epiphytic algae of occurring on submerged macrophytes are a source of food for invertebrates. Submerged macrophyte and phytoplankton components of eutrophic, shallow lakes have frequently undergone dynamic changes in composition and abundance, with important consequences for lake functioning and stability [27]. Studies carried out in three Swedish lakes of different trophy found a correlation between the density of periphitic nematodes and algae content: they both increase with increasing trophic status of the lake. This result indicates that the potential availability of microalgae may favor the presence of nematodes [28].

Macrophytes are a group of aquatic organisms affected by constant changes. One of the main factors influencing the rate and direction of these changes is water body management. The water level fluctuations are important in modifying the shore zone and in substrate sorting, and thus in maintaining suitable habitat for rare species of macrophytes [29-31].

The study of species composition and structure of the species diversity of nematodes associated with species of elodeids showed no differences in the number of nematodes between macrophyte species. A slight difference in species diversity of nematodes with respect to various species of macrophytes has been reported, which consequently was not statistically significant [32].

The higher density of meioinvertebrates on elodeids than in bottom sediments of the studied reservoirs may be due to the fact that complex structured aquatic plants provide them with effective shelter [33]. Furthermore, the higher density of meioinvertebrates among aquatic vegetation than in bottom sediments may result from favorable physico-chemical properties of the substrate, among which are oxygen concentration and the availability of food [34].

The similarity of elodeid meioinvertebrate fauna in the oligotrophic pond to the one of eutrophic Lake Bikcze and of the peat-hag amounted to 55 and $51 \%$, respectively. In the case of low-fertility water bodies such as the oligotrophic pond and mesotrophic Lake Piaseczno, the similarity of elodeid meioinvertebrate fauna was found to be $95 \%$. Low values of similarity of epiphytic fauna in reservoirs of different trophic status and similar vegetation structure allow one to conclude that the trophic status of the reservoir exerts an important effect on the development of a given community of epiphytic meioinvertebrates. In studies conducted in Lake Sakadaš (Croatia), it was demonstrated that the composition of invertebrates associated with macrophytes (M. spicatum L.) is consistent with the trophy of the studied lake [35]. Some elodeids, for example M. spicatum L., typically occur on mineral surfaces of meso to eutrophic lakes [36].

Analysis of various research results shows that the character of vegetation is not the main factor determining the density and diversity of invertebrates, which has 
already been shown for gastrotrich communities of peathags and lakes $[4,6]$.

\section{Conclusions}

1. The density of invertebrate fauna living on elodeids is significantly higher than the density of fauna that live in bottom sediments.

2. The highest density of benthic and epiphytic meioinvertebrate fauna was recorded in the eutrophic reservoirs.

3. Epiphytic meioinvertebrate fauna in the reservoirs of high trophic level show low similarity to the oligotrophic.

4. The development of the meioinvertebrate community on elodeids is mainly affected by trophic status of reservoirs and not by character of vegetation.

\section{References}

1. HARPER J.L., HAWKSWORTH D.L. Preface. [In:] Hawksworth D L (ed.) Biodiversity measurement and estimation. Chapman and Hall. London, 5-12, 1996.

2. TOPOROWSKA M., PAWLIK-SKOWROŃSKA B., WOJTAL A. Z. Epiphytic algae on Stratiotes aloides L., Potamogeton lucens L., Ceratophyllum demersum L. and Chara spp. in a macrophyte-dominated lake. Oceanological and Hydrobiological Studies. 37 (2), 51, 2008.

3. TARKOWSKA-KUKURYK M., KORNIJÓW R. Influence of spatial distribution of submerged macrophytes on chironomids assemblages in shallow lakes. Pol. J. Ecol. 56, 569, 2008.

4. NESTERUK T. Comparison of gastrotrich fauna of elodeids and in bottom sediments of lakes of different trophic statuss (the region Polesie Lubelskie. Eastern Poland). Oceanological and Hydrobiological Studies. 40 (2), 13, 2011.

5. NESTERUK T. Quantitative assessments of benthic and epiphytic fauna of meioinvertebrates of small water bodies of anthropogenic origin. TEKA commission of protection and formation of natural environment. 9, 134, 2012

6. NESTERUK T. Gastrotrich fauna of elodeids and bottom sediments in a eutrophic lake. TEKA commission of protection and formation of natural environment. 6, 206, 2009.

7. KORNIJÓW R. Seasonal migration by larvae of en epiphytic chironomid. Freshwat. Biol. 27, 85, 1992.

8. KORNIJÓW R., KAIRESALO T. A simple solution enabling quantitative sampling of freshwater and marine sediments covered by dense submerged vegetation. Hydrobiologia. 716, 1, 2013.

9. PŁASKA W. Qualitative and quantitative structure of Heteroptera aquatica in the shallow littoral of selected water bodies in Łęczna-Włodawa lake district. TEKA commission of protection and formation of natural environment. 6, 228, 2009.

10. SERAFIN A., CZERNAŚ K. Phytoplankton productivity in littoral of selected lakes in Łęczna-Włodawa Lakeland in summer 2007-2008. TEKA commission of protection and formation of natural environment. 6, 311, 2009.

11. RIEDL R. Probleme und Methoden der Erforschung des litoralen Benthos. Verh. Dtsch. Zool., Suppl., 26, 505, 1963.
12. NESTERUK T. Density and biomass of Gastrotricha in sediments of different types of standing waters. Hydrobiologia. 32, 20, 1996.

13. SEGARS H. Global diversity of rotifers (Rotifera) in freshwater. Hydrobiologia. 595, 49, 2008.

14. BRACCINI J. A. L., LEAL-ZANCHET A. M. Turbellarian assemblages in freshwater lagoons in southern Brazil. Invertebrate Biology. 132 (4), 305, 2013.

15. TRAUNSPURGER W., HÖSS S., WITTHÖFT-MÜHLMANN A., WESSELS M., GÜDE H. Meiobenthic community patterns of oligotrophic and deep lake Constance in relation to water depth and nutrients. Fundamental and Applied Limnology. 180, 233, 2012.

16. SPIETH H. R., MÖLLER T., PTATSCHEK C., KAZEMIDINAN A., TRAUNSPURGER W. Meiobenthos provides a food resource for young cyprinids. Journal of Fish Biology. 78, 138, 2011.

17. WEBER S., TRAUNSPURGER W. Top-down control of a meiobenthic community by two juvenile freshwater fish species. Aquatic Ecology. 48, 465, 2014.

18. RISTAU K., TRAUNSPURGER W. Relation between nematode communities and trophic state in southern Swedish lakes. Hydrobiologia. 663 (1), 121, 2011.

19. TARKOWSKA-KUKURYK M., Comparative study of epiphytic and benthic fauna of shallow eutrophic lake of Poleski National Park. TEKA commission of protection and formation of natural environment. 7, 428, 2010.

20. BASIŃSKA A., KUCZYŃSKA-KIPPEN N. Differentiated macrophyte types as a habitat for rotifers in small mid-forest water bodies. Biologia. 64 (6), 1100, 2009.

21. DEMETRAKI-PALEOLOG A. Planktonic Rotifers of four polimictic lakes of Łęczyńsko-Wlodawskie Lakeland (Eastern Poland). TEKA commission of protection and formation of natural environment. 6, 35, 2009.

22. SENDER J. Changes in structure of macrophyte communities in the chosen lakes of Łęczna-Włodawa Lake District. Ecohydrol. Hydrobiol. 9 (2-4), 237, 2009.

23. SONDERGAARD M., JOHANSSON L.S., LAURIDSEN T.L., JORGENSEN T.B., LIBORIUSSEN L., JEPPESEN E. Submerged macrophytes as indicators of the ecological quality of lakes. Freshwat. Biol. 55, 893, 2010.

24. STRAYER D.L., DUDGEON D. Freshwater biodiversity conservation: recent progress and future challenges. Journal of the North American Benthological Society. 29, (1), 344, 2010.

25. SAYER C.D., DAVIDSON T.A., JONES J.I. Seasonal dynamics of macrophytes and phytoplankton in shallow lakes: a eutrophication-driven pathway from plants to plankton? Freshwater Biology 55 (3), 500, 2010.

26. BAKKER E.S., SARNEEL J.M., GULATI R.D., LIU Z., VAN DONK E. Restoring macrophyte diversity in shallow temperate lakes: biotic versus abiotic constraints. Hydrobiologia. 710, 23, 2013.

27. SAYER C.D., BURGESS A., KARI K., DAVIDSON T.A., PEGLAR S., YANG H., ROSE N. Long-term dynamics of submerged macrophytes and algae in a small and shallow, eutrophic lake: implications for the stability of macrophytedominance. Freshwater Biology 55, 565, 2010.

28. KAZEMI-DINAN A., SCHROEDER F., PETERS L., MAJDI N., TRAUNSPURGER W. The effect of trophic state and depth on periphytic nematode communities in lakes. Limnologica. 44, 49, 2014

29. SENDER J. The dynamics of macrophytes in a lake in an agricultural landscape. Limnological Review. 12 (2), 93, 2012.

30. KOWALEWSKI G.A., KORNIJÓW R., MC GOWAN S., WOSZCZYK M., KACZOROWSKA A., BAŁAGA K., 
SUCHORA M., SZEROCZYŃSKA K., GĄSIOROWSKI M., WASIŁO A. Persistence of protected, vulnerable macrophyte species in a small, shallow eutrophic lake (eastern Poland) over the past two centuries: implications for lake management and conservation. Aquatic Botany. 106, 1, 2013.

31. NAGENGAST B., KUCZYŃSKA-KIPPEN N. The effect of human impact on the vegetation of small water bodies in an agricultural landscape. TEKA commission of protection and formation of natural environment. 10, 274, 2013.

32. VIDAKOVIČ J., PALIJAN G. Development and functional structure of epiphytic nematode communities on the submerged macrophyte Ceratophyllum demersum in Lake Sakadaš, Kopački Rit, Croatia. Nematology. 12 (2), 289, 2010.
33. IGLESIAS C., GOYENELA N.G., MAZZEO N. Horizontal dynamics of zooplankton in subtropical lake blanca (Uruguay) hosting multiple zooplankton predators and aquatic plant refuges. Hydrobiologia 584 (1),179, 2007.

34. KUCZYŃSKA-KIPPEN N. Habitat choice in rotifera communities of three shallow lakes: impact of macrophyte substratum and season. Hydrobiologia. 593, 27, 2007.

35. ČERBA D., BOGUT I., VIDAKOVIĆ J., PALIJAN G. Invertebrates in Myriophyllum spicatum L. stands in Lake Sakadaš, Croatia. Ekologia (Bratislava) 28 (1), 94, 2009.

36. KŁOSOWSKI S., JABŁOŃSKA E., SZAŃKOWSKI M. Aquatic vegetation as an indicator of littoral habitats and various stages of lake aging in north-eastern Poland. Int. J. Limnol. 47, 281, 2011. 